\title{
Diquat Used as a Preharvest Desiccant Affects Seed Germination of Spinach, Table Beet, and Coriander
}

\author{
Timothy W. Miller ${ }^{1}$ \\ Washington State University, 16650 State Route 536, Mt. Vernon, WA 98273 \\ Additional index words. vegetable seed, seed production, Spinacia oleracea, Beta vulgaris, \\ Coriandrum sativum
}

\begin{abstract}
Diquat was tested to determine its suitability for use as a preharvest desiccant of selected vegetable seed crops during 1997 and 1998. In separate studies, diquat was applied at $0,0.56$, or $1.12 \mathrm{~kg} \cdot \mathrm{ha}^{-1}$ a.i. to spinach (Spinacia oleracea L.), table beet (Beta vulgaris L.), and coriander (Coriandrum sativum L.) plants at usual swathing time. Except for beet seed in 1998, there was no clear trend toward reduced seed weight with increasing diquat rate. Spinach seed germination in 1998 and coriander seed germination in 1997 were reduced by diquat at $1.12 \mathrm{~kg}^{-h^{-1}}$ compared to seed from nontreated plants or plants treated with $0.56 \mathrm{~kg} \cdot \mathrm{ha}^{-1}$. In all crops, diquat at $0.56 \mathrm{~kg} \cdot \mathrm{ha}^{-1}$ was adequate for crop desiccation purposes. However, seed producers should consider the potential benefits from chemical desiccation that may potentially lower germination of the harvested seed. Chemical name used: 6,7-dihydrodipyrido[1,2- $\left.\alpha: 2^{\prime}, 1^{\prime}-c\right]$ pyrazinediium ion (diquat).
\end{abstract}

Harvest of vegetable seed crops is often complicated by green leaves and stems and immature seed on the crop plant. Threshing thoroughly dry plants results in cleaner seed with less need for post-harvest drying, reduces mechanical damage to seed and the spread of disease inoculum, lessens machinery wear, and speeds combining (Gubbels and Dedio, 1985). The presence of green weeds also reduces harvest efficiency and lowers seed quality (Ross and Lembi, 1985).

Swathing (mechanically cutting plants at the soil line and lying them in windrows) and chemical desiccation are commonly used to dry crop plants and weeds prior to harvest. One of the most commonly-used chemical desiccants is diquat (Reglone diquat desiccant; Syngenta Crop Protection, Greensboro, N.C.). While useful, chemical desiccation must be carefully timed to prevent reduction in seed yield and quality. Although swathing reduced spring wheat (Triticumaestivum L., nom. cons.) head moisture more quickly than diquat application, early swathing reduced test weight and yield more than similarly timed diquat ( $\mathrm{McNeal}$ et al., 1973). Plant drying after desiccant application also may not be as thorough as swathing. Diquat application rapidly defoliates plants but stem drying proceeds more slowly, both in flax (Linum usitatissimum L.) (Gubbels and Kenaschuk, 1981) and sunflower (Helianthus annuus L.) (Gubbels and Dedio, 1985). The speed of desiccation is also influenced by diquat rate (Gubbels and Kenaschuk, 1981)

Received for publication 9 Aug. 2001. Accepted for publication 2 Jan. 2002. Funding for these trials was received from the Washington State Commission on Pesticide Registration and the Puget Sound Seed Growers Association.

${ }^{1}$ Current address: Washington State Univ., 16650 State Route 536, Mount Vernon, WA 98273. E-mail: twmiller@wsu.edu and timing (Gubbels et al., 1993b). When applied to sunflower prior to achene maturity, diquat reduced yield, oil content, 1000-achene weight, test weight, and protein content (Gubbels and Dedio, 1985). Flax yielded best when $75 \%$ of the seed capsules were brown and the crop swathed at $30 \%$ moisture or treated with diquat at $29 \%$ moisture (Gubbels et al., 1993a). Flax treated at $75 \%$ to $50 \%$ green capsule stage yielded lower than nontreated, swathed plants (Gubbels and Kenaschuk, 1981). Finch et al. (1972) cited a potential link between diquat and increased hard seed production in clover (Trifolium spp.) and alfalfa (Medicago sativa L.). However, Moyer et al. (1996) found that treated and nontreated alfalfa both yielded $\approx 60 \%$ hard seed. They also determined that alfalfa should be treated at $>60 \%$ brown pods to maximize seed yield.

The potential for reduced seed germination is a concern with use of diquat in vegetable seed production. Crop seeds react differently to diquat application. Seed germination of flax treated with diquat at $75 \%$ to $50 \%$ green capsule stage was poorer than plants treated at a more mature stage (Gubbels and Kenaschuk, 1981). Diquat application to perennial ryegrass (Lolium perenne L.) reduced seed germination and increased the frequency of abnormal seedlings (Roberts and Griffiths, 1973). Conversely, Bovey and McCarty (1965) found that treated sorghum (Sorghum vulgare Pers.) had higher seed germination and lower seed moisture than nontreated plants. They also found that seed from treated sorghum held in storage for a year germinated at a similar rate as freshly harvested seed. Diquat applied to alfalfa was not detrimental to seed germination (Finch et al., 1972; Moyer et al., 1996; Rincker et al., 1988).

In the maritime environment of northwestern Washington during late summer and au- tumn, drying of the swathed windrow usually requires two or more weeks, even under optimal conditions. Soil moisture levels at this time are normally high enough to allow for substantial basal regrowth of swathed weeds and crop plants, sometimes extending the postswathing drying time by a week or more. If cool and cloudy conditions occur, as they often do, regrowth is accelerated, drying is slowed, and combining becomes increasingly difficult. A chemical desiccant that slows regrowth, reduces crop drying time, or both, while not lowering seed yield or germination, would be an excellent option for vegetable seed growers in this region. The objective of these field trials was to determine the effect of preharvest diquat applications on seed germination of spinach, table beet, and coriander.

\section{Materials and Methods}

In separate field trials in 1997 and 1998 , diquat was applied to spinach ('Medania'), table beet ('Detroit Dark Red Medium Tops'), and coriander ('Pokey Joe') plants at $0,0.56$, or $1.12 \mathrm{~kg} \cdot \mathrm{ha}^{-1}$ a.i. at normal swathing time Diquat applications were made 12 Aug. and 17 Aug. in spinach, 10 Sept. and 31 Aug. in beets, and 25 Sept. and 3 Sept. in coriander (1997 and 1998, respectively). A tractor-mounted boom sprayer was used to apply diquat in all crops both years. The boom was equipped with 8002 flat fan nozzles spaced $50.8 \mathrm{~cm}$ apart $(3.04-\mathrm{m}$ boom) delivering $389 \mathrm{~L} \cdot \mathrm{ha}^{-1}$ at $206 \mathrm{kPa}$. Plots measured $9.1 \mathrm{~m}$ long $\times 1.5 \mathrm{~m}$ wide and included two crop rows on a $76.2-\mathrm{cm}$ spacing.

In the spinach trials, standing plants were allowed to desiccate for 2 weeks following diquat application, after which 10 spinach plants from each plot were randomly selected, cut, and fully dried in a greenhouse prior to threshing. Ten nontreated plants were cut from the check plot on the day of diquat application, allowed to dry in the field for 2 weeks, then fully dried in a greenhouse. Harvest procedures for beet and coriander plants was similar to spinach, except five plants were selected rather than 10 .

Seeds were threshed by hand when seed moisture was $10 \%$ to $12 \%$. Leaf and stem material was removed and undersized, offcolored, and shriveled seeds were discarded. Seeds were not graded by density and no other conditioning operations were conducted. Because threshing and cleaning techniques differed widely from commercial vegetable seed production practices, extrapolated field-based yields were not calculated. Seed samples were kept in paper packets within an enclosed storage building [approximate temperature range from 10 to $20^{\circ} \mathrm{C}$ and relative humidity from $40 \%$ to $55 \%$ ] during the 3 months before germination tests were conducted.

Four hundred seeds of each crop were selected from each treatment for germination testing each year ( 100 seeds per replicate, four replicates total). Care was taken to select seed as similarly sized as possible for these tests. Spinach seeds were placed between moist paper toweling and germinated at alternating $15 / 10^{\circ} \mathrm{C}$ temperatures for $16 / 8 \mathrm{~h}$, respec- 
tively, with counts made at 4,7 , and $14 \mathrm{~d}$ (after Ashton, 2000). Beet seeds were soaked in water for $2 \mathrm{~h}$ at $24{ }^{\circ} \mathrm{C}$, blotted dry, then placed between moist paper toweling and germinated at alternating $20 / 30^{\circ} \mathrm{C}$ temperatures for $16 / 8 \mathrm{~h}$, respectively, with counts made at 3 , 7, and $14 \mathrm{~d}$ (Ashton, 2000). Coriander seeds were placed between moist paper toweling and germinated at $15^{\circ} \mathrm{C}$ with counts made at $6,11,14$, and $21 \mathrm{~d}$ (Ashton, 2000). The number of abnormal seedlings occurring during germination testing was noted and tallied as nongerminated seeds. Abnormal seedlings were defined as those with incomplete cotyledon emergence from the seed coat, those in which the radicle failed to emerge, or those dying shortly after radicle emergence. Prior to germination, each 100 -seed replicate was weighed and 1000 -seed weights calculated

In addition to germination percentage, a weighted germination index (GI) was calculated (Walker-Simmons, 1988):

$$
\mathrm{GI}=\frac{\left(7 n_{1}+6 n_{2}+\ldots+1 n_{7}\right)}{\text { (total days) (total seeds) }}
$$

where $n_{1}, n_{2}, \ldots$, and $n_{7}$ are the number of seeds germinated on the first, second, and subsequent days until the seventh day of a 7-d germination trial, respectively; $7,6, \ldots$, and 1 are the coefficients given to the number of seed germinated on the first, second, and subsequent days, respectively, of this 7-d test. A maximum GI in this system is 1.0 .

The experimental design for each trial was a randomized complete block with four replicates. Data were analyzed using analysis of variance (ANOVA) procedure. Log transformation of germination responses did not produce significant changes in ANOVA results, so data presented are actual values. ANOVA performed on total germination showed that these responses differed significantly by year, so these data were analyzed separately for 1997 and 1998. All statistical computations were carried out using SAS Statistical Software (SAS Institute, 1990).

\section{Results and Discussion}

Diquat at $0.56 \mathrm{~kg} \cdot \mathrm{ha}^{-1}$ was adequate for desiccation of spinach, table beet, and coriander plants in both years (data not shown). Application of diquat at $1.12 \mathrm{~kg} \cdot \mathrm{ha}^{-1}$ did not appreciably accelerate crop desiccation, nor more thoroughly defoliate treated plants than the $0.56 \mathrm{~kg} \cdot \mathrm{ha}^{-1}$ rate.

Thousand-seed weights for table beet and coriander did not significantly differ between years (main effect), although both crops exhibited significant responses to diquat rate and to the interaction between rate and year. Therefore, data were pooled for both years and the interaction data are provided (Table 1). Beet seed in 1997 was significantly lighter than in 1998 regardless of diquat rate, but no other trend was clear in the beet data. In 1997, 1000seed weights were greatest from beets treated with diquat at $0.56 \mathrm{~kg} \cdot \mathrm{ha}^{-1}(16.8 \mathrm{~g})$, while seed from beets either treated with $1.12 \mathrm{~kg} \cdot \mathrm{ha}^{-1}$ or left untreated were significantly lighter (14.3 and $14.4 \mathrm{~g}$, respectively). However, in 1998 nontreated beets produced the heaviest seed $(21.1 \mathrm{~g})$, while plants treated at 0.56 or 1.12 $\mathrm{kg} \cdot \mathrm{ha}^{-1}$ resulted in significantly lighter seed ( 19.0 and $19.8 \mathrm{~g}$, respectively). Coriander seed response to diquat was also mixed, as there were no significant differences in 1000-seed weights in 1997 (ranging from 8.9 to $9.1 \mathrm{~g}$ ), while the lightest seed $(8.1 \mathrm{~g}$ ) was produced on nontreated coriander plants in 1998. The heaviest seed produced either year resulted from coriander treated with 0.56 or $1.12 \mathrm{~kg} \cdot \mathrm{ha}^{-1}$ in 1998 (9.9 and $9.4 \mathrm{~g}$, respectively). Based on these data, it appears diquat desiccation at this stage of growth has little detrimental effect on table beet or coriander seed weight.

Diquat rate did not affect 1000 -seed weight of spinach in either year, although responses were significantly different between 1997 and 1998 (Table 1). There was no interaction between diquat rate and year. This indicates a low potential for seed weight reduction from diquat application to spinach at normal swathing time.

Germination percentages of spinach, table beet, and coriander seed were significantly different between 1997 and 1998, so data were analyzed separately for each crop by year (Table 2). Treatment of spinach with diquat at $0.56 \mathrm{~kg} \cdot \mathrm{ha}^{-1}$ did not significantly lower seed germination compared to nontreated plants in 1998, although germination of seed from spinach treated with $1.12 \mathrm{~kg} \cdot \mathrm{ha}^{-1}$ in 1998 was reduced to $31 \%$, compared to $64 \%$ from nontreated plants. Seed germination was also reduced by diquat at the higher rate compared to the low rate or nontreated plants in 1997 , although not significantly so $(P=0.36)$.

Table beet seed was tolerant to diquat in these studies. Seed germination percentage was not significantly reduced by diquat applied at normal swathing time in either year $(P=$ 0.05 ), although 1998 beet seed germination was reduced by the higher rate of diquat at the $P=0.07$ level of significance $(96 \%$ and $87 \%$ for nontreated plants and those treated with $1.12 \mathrm{~kg} \cdot \mathrm{ha}^{-1}$, respectively).

Germination of coriander seed in 1997 was 13 percentage points lower from plants treated with diquat at $1.12 \mathrm{~kg} \cdot \mathrm{ha}^{-1}$ compared to seed from nontreated plants $(62 \%$ and $49 \%$, respectively). Diquat at $0.56 \mathrm{~kg} \cdot \mathrm{ha}^{-1}$ did not significantly reduce coriander seed germination in either year.

Statistical analyses of spinach, table beet, and coriander seed GI from 1997 and 1998 did not result in significant differences from total seed germination, so GI values are not presented. The weighted GI is an indicator of seed vigor, since the rapidity of seed germination was factored into the calculations (WalkerSimmons, 1988). The similarities in responses between germination percentage and GI in these studies provides further evidence that the vigor of spinach, beet, and coriander seed was not impaired by preharvest desiccation by diquat.

Seedlots from all tested crops produced some abnormal seedlings during germination testing. The incidence of abnormal seedlings did not exceed $5 \%$ in any seedlot; however, the number of abnormal seedlings was not increased by diquat application (data not shown). Therefore, preharvest desiccation of these vegetable seed crops using diquat did not induce seedling abnormalities.

The low seed germination percentages of nontreated spinach in 1997 and $1998(72 \%$ and $64 \%$, respectively) and coriander in 1997 $(62 \%)$ may be attributed to precipitation patterns during seed ripening and immediately preharvest (Table 3). Spinach plants were

Table 1. Thousand-seed weights of table beet, coriander, and spinach seed harvested from plants desiccated with diquat (interaction of diquat rate $\times$ year).

\begin{tabular}{|c|c|c|c|c|c|c|}
\hline \multirow{2}{*}{$\begin{array}{l}\text { Diquat rate } \\
\left(\mathrm{kg} \cdot \mathrm{ha} \mathrm{a}^{-1}\right)\end{array}$} & \multicolumn{2}{|c|}{ Table beet seed ${ }^{2}$} & \multicolumn{2}{|c|}{ Coriander seed $^{2}$} & \multicolumn{2}{|c|}{ Spinach seedy } \\
\hline & 1997 & 1998 & 1997 & 1998 & 1997 & 1998 \\
\hline & \multicolumn{6}{|c|}{ 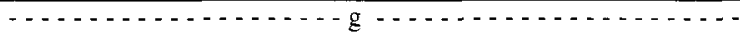 } \\
\hline 0 & $14.4 \mathrm{~d}^{x}$ & $21.1 \mathrm{a}$ & $8.9 \mathrm{~b}$ & $8.1 \mathrm{c}$ & 11.2 & 10.8 \\
\hline 0.56 & $16.8 \mathrm{c}$ & $19.0 \mathrm{~b}$ & $9.0 \mathrm{~b}$ & $9.9 \mathrm{a}$ & 11.9 & 10.8 \\
\hline 1.12 & $14.3 \mathrm{~d}$ & $19.8 \mathrm{~b}$ & $9.1 \mathrm{~b}$ & $9.4 a b$ & 12.2 & 10.9 \\
\hline $\mathrm{LSD}_{0.05}$ & \multicolumn{2}{|c|}{1.0} & \multicolumn{2}{|c|}{0.6} & NS & NS \\
\hline
\end{tabular}

${ }^{2}$ Rate $\times$ year interaction significant; data are pooled across years.

${ }^{y}$ Rate $\times$ year interaction nonsignificant; data are separated between years.

${ }^{\mathrm{x}} \mathrm{a}-\mathrm{d}=$ means with the same letter are not significantly different using Fisher's Protected LSD $(P=0.05)$; NS $=$ no means are significantly different.

Table 2. Germination percentage of spinach, table beet, and corriander seed harvested from plants dessicated with diquat.

\begin{tabular}{|c|c|c|c|c|c|c|}
\hline \multirow{2}{*}{$\begin{array}{l}\text { Diquat rate } \\
\left(\mathrm{kg} \cdot \mathrm{ha}^{-1}\right)\end{array}$} & \multicolumn{2}{|c|}{ Spinach seed ${ }^{2}$} & \multicolumn{2}{|c|}{ Table beet seed ${ }^{z}$} & \multicolumn{2}{|c|}{ Coriander seed } \\
\hline & 1997 & 1998 & 1997 & 1998 & 1997 & 1998 \\
\hline & $-\cdots$ & $\cdots$ & Germ & on $(\%)$ & $\cdots$ & - \\
\hline 0 & 72 & $64 a^{x}$ & 91 & 96 & $62 a$ & 84 \\
\hline 0.56 & 69 & $61 \mathrm{a}$ & 89 & 94 & $60 \mathrm{a}$ & 75 \\
\hline 1.12 & 60 & $31 \mathrm{~b}$ & 88 & 87 & $49 \mathrm{~b}$ & 78 \\
\hline $\mathrm{LSD}_{0.05}$ & NS & 24 & NS & NS & 7 & NS \\
\hline
\end{tabular}

zercent germination after $14 \mathrm{~d}$; seed germinated 3 months after harvest. yPercent germination after $21 \mathrm{~d}$; seed germinated 3 months after harvest. ${ }^{x} \mathrm{a}-\mathrm{b}=$ means with the same letter are not significantly different using Fisher's protected LSD $(P=0.05)$; NS $=$ no means are significantly different. 
Table 3. Precipitation at Mount Vernon, Wash. ${ }^{2}$, during seed ripening and drying of vegetable seed crops in these studies.

\begin{tabular}{lrcc}
\hline & \multicolumn{3}{c}{ Precipitation (mm) } \\
\cline { 2 - 4 } Month & 1997 & 1998 & 10 -year avg \\
\hline August & 12 & 1 & 28 \\
September & 80 & 10 & 38 \\
October & 130 & 69 & 82 \\
\hline
\end{tabular}

${ }^{2}$ Data collected at an automated station at Washington State Univ. Research and Extension Unit near Mount Vernon, Wash.

treated in August in both years, when monthly precipitation was $43 \%$ and $4 \%$ of normal (1997 and 1998, respectively). Dry conditions during seed filling may detrimentally affect seed germination and vigor (Harrington, 1971), perhaps due to the effect of low soil moisture on solubility of nutrients essential to growth of the mother plant (McDonald and Copeland, 1997). Because these plants were not irrigated, it is reasonable to speculate that spinach seed quality may have been reduced due to water stress, particularly in 1998. Conversely, coriander plants in 1997 were treated in late September and harvested in mid October. Precipitation was $175 \%$ of normal in September and Oct. 1997, probably contributing to preharvest shatter of ripe seed and perhaps also resulting in sprouting of seed in the field (McDonald and Copeland, 1997). Collectively, quality of harvested coriander seed was poorer in 1997 than in 1998, when precipitation was $66 \%$ of normal resulting in $84 \%$ germination.

Treating with $0.56 \mathrm{~kg} \cdot \mathrm{ha}^{-1}$ diquat did not significantly reduce germination of spinach, table beet, or coriander seed in either year, as compared to seed from nontreated plants. While $1.12 \mathrm{~kg} \cdot \mathrm{ha}^{-1}$ reduced germination compared to plants treated at $0.56 \mathrm{~kg} \cdot \mathrm{ha}^{-1}[30 \%$ spinach (1998) and $11 \%$ in coriander (1997)], neither the increase in germination for coriander in 1998 nor the reductions for spinach in 1997 and beet in either year were statistically significant. Thus, it appears that diquat does not significantly reduce seed germination of these vegetable seed crops unless rates in excess of $0.56 \mathrm{~kg} \cdot \mathrm{ha}^{-1}$ are used.
The primary value of diquat applied to vegetable seed crops in northwestern Washington may be the potential for slowing weed regrowth in treated plots as compared to swathing alone. Although not measured directly in these trials, swathed plants regrew more quickly than diquat-treated plants. Similarly, in preliminary studies conducted by the author, diquat applied to freshly swathed plants in a heavily weed-infested table beet seed field slowed regrowth of weed and crop stubble by 5 to $7 \mathrm{~d}$ compared to swathing alone (unpublished data). The usefulness of diquat applied pre- or post-swathing is being investigated.

Although the observed $2 \%$ to $9 \%$ reductions in seed germination from diquat at 0.56 $\mathrm{kg} \cdot \mathrm{ha}^{-1}$ were not statistically significant in these trials, even such minor losses in germination may be unacceptable in practice. If environmental conditions prior to harvest were not generally favorable for seed production (e.g., plants stressed due to insufficient or excessive precipitation), seed quality may already be marginal and diquat desiccation could result in germination percentage falling below marketable levels. Therefore, it is advisable for vegetable seed growers to carefully evaluate the potential for lost germination before using diquat to chemically desiccate their crop.

Based on these results, it is concluded that harvest ripe table beet seed will tolerate diquat applied up to $1.12 \mathrm{~kg} \cdot \mathrm{ha}^{-1}$, but harvest ripe coriander or spinach seed should not be treated with diquat at greater than $0.56 \mathrm{~kg} \cdot \mathrm{ha}^{-\mathrm{i}}$. Because desiccation from $0.56 \mathrm{~kg} \cdot \mathrm{ha}^{-1}$ was adequate for all the vegetable seed crops in these trials, higher application rates are not required. However, seed producers should weigh the potential benefits from chemical desiccation (improved harvest efficiency, slowed regrowth, hastening of drying) with potentially lower germination of the harvested seed prior to using diquat.

\section{Literature Cited}

Ashton, D. (ed.). 2000. Rules for testing seeds. Assn. of Official Seed Analysts, Lincoln, Nebr. Bovey, R.W. and M.K. McCarty. 1965. Effect of pre-harvest desiccation on grain sorghum. Crop Sci. 5:523-526.

Finch, C.G., W.E. Bray, E.G. Budd, W.G. Gwynne, P.C. Longden, and H. Mead. 1972. Recommendations for the control of weeds in seed crops, $p$. 171-182. In: J.D. Fryer and R.J. Makepeace (eds.). Weed control handbook, volume II, recommendations. 7th edition. Blackwell Scientific Publications, Oxford.

Gubbels, G.H., D.M. Bonner, and E.O. Kenaschuk. 1993a. Effect of swathing and desiccation time on seed yield and quality of flax. Can. J. Plant Sci. 73:397-404.

Gubbels, G.H., D.M. Bonner, and E.O. Kenaschuk. 1993b. Effect of time of swathing and desiccation on plant drying, seed color and germination of flax. Can. J. Plant Sci. 73:1001-1007.

Gubbels, G.H. and W. Dedio. 1985. Desiccation of sunflower with diquat. Can. J.Plant Sci. 65:841847.

Gubbels, G.H. and E.O. Kenaschuk. 1981. Desiccation of flax with diquat. Can. J. Plant Sci. 61:575581.

Harrington, J.F. 1971. The necessity for high quality vegetable seed. HortScience 6:550-551.

McDonald, M.B. and L.O. Copeland. 1997. Environmental effects on seed development, p. 2628. In: Seed production principles and practices. Chapman \& Hall, New York.

McNeal, F.H., J.M. Hodgson, C.F. McGuire, and M.A. Berg. 1973. Chemical desiccation experiments with hard red spring wheat, Triticum aestivum L. Agron. J. 65:451-453.

Moyer, J.R., S.N. Acharya, J. Fraser, K.W. Richards, and N. Foroud. 1996. Desiccation of alfalfa for seed production with diquat and glufosinate. Can. J. Plant Sci. 76:435-439.

Rincker, C.M., V.L. Marble, D.E. Brown, and C.A Johansen. 1988. Seed production practices, $p$ 985-1021. In: A.A. Hanson, D.K. Barnes, and R.R. Hill (eds.), Alfalfa improvement. Amer. Soc. Agron., Madison, Wis., Agron. No. 29.

Roberts, H.M. and D.J. Griffiths. 1973. Pre-harvest desiccation of herbage seed crops and its effect on seed quality. J. Br. Grassld. Soc. 28:189-192.

Ross, M.A. and C.A. Lembi. 1985. Characteristics and importance of weeds, p. 1-19. In: Applied weed science. Burgess Publishing Co., Minneapolis.

SAS Institute. 1990. SAS software version 8.0. SAS Inst., Cary, N.C.

Walker-Simmons, M. 1988. Enhancement of ABA responsiveness in wheat embryos by high temperature. Plant, Cell and Environ. 11:769-775. 